\title{
FAKTOR PENYEBAB ANAK PUTUS SEKOLAH (Studi di Desa Mapila Kecamatan Kabaena Utara Kabupaten Bombana)
}

\author{
Ridwan $^{1}$, Irawaty2, Abdul Halim Momo ${ }^{3}$ \\ Jurusan Pendidikan Pancasila dan Kewarganegaraan \\ Fakultas Keguruan dan Ilmu Pendidikan \\ Universitas Halu Oleo \\ Email: ${ }^{1}$ Unitedridwan1@gmail.com, irawaty@gmail.com², \\ abdulhalimmomo@gmail.com ${ }^{3}$
}

\begin{abstract}
Abstrak: Tujuan penelitian ini adalah: 1) Untuk mengetahui faktor yang menjadi penyebab anak putus sekolah di desa mapila kecamatan kabaena utara kabupaten bombana, 2) Untuk mengetahui upaya orang tua dan sekolah dalam mengatasi anak putus sekolah studi di desa mapila kecamatan kabaena utara kabupaten bombana. Jenis Penelitian ini adalah deskriptif dengan menggunakan campuran (Mix Method). Responden penelitian ini sebanyak 14 orang anak yang putus sekolah, dan informan penelitian yaitu berjumlah 10 orang.Teknik pengumpulan data dalam penelitian ini adalah angket, observasi, wawancara dan dokumentasi. Hasil penelitian ini menunjukkan faktor penyebab anak putus sekolah terbagi dua yaitu faktor internal yaitu rendahnya minat atau kemauan anak untuk bersekolah, sekolah dianggap tidak menarik dan ketidakmampuan dalam mengikuti pelajaran sedangkan faktor eksternal yaitu ekonomi keluarga, kurangnya perhatian orang tua, lingkungan bermain anak dan jauhnya jarak antara rumah dan sekolah. Upaya untuk mengatasi anak putus sekolah dilakukan dengan cara: 1) Upaya orang tua adanya perhatian akan pentingnya pendidikan formal dengan memberikan dukungan dan motivasi baik dari segi moral maupun material, rasa peduli, menjalin kedekatan dengan anak, mendampingi anak ketika berada di rumah dan mengontrol pergaulan anak, 2) Upaya sekolah dengan menjalin kedekatan dengan siswa dan orang tua siswa, pemanggilan orang tua siswa, untuk kemudian mencari solusi agar anak tetap melanjutkan pendidikan formal. Kesimpulan penelitian ini yaitu: faktor penyebab anak putus sekolah di desa Mapila terdiri dari dua faktor yaitu faktor internal yang mendominasi yaitu rendahnya minat dan kemauan anak untuk bersekolah dan faktor eksternal yang mendominasi yaitu adalah kurangnya perhatian orang tua sedangkan upaya orang tua dalam mengatasi anak putus sekolah di desa mapila yaitu:sadar akan pentingnya pendidikan anak, memberikan dukungan dan motivasi baik dari segi moral maupun material serta mengontrol pergaulan anak. Upaya pihak sekolah dengan menjalin kedekatan dengan siswa dan orang tua siswa, pemanggilan serta mengunjungi orang tua siswa untuk bersama mencari solusi agar anak tetap melanjutkan pendidikan formal.
\end{abstract}

\section{Kata Kunci: Putus Sekolah, Faktor Penyebab, Upaya Orang Tua Dan Sekolah}

\section{PENDAHULUAN}

Pendidikan merupakan usaha sadar yang diperuntukkan oleh seluruh manusia yang bersifat universal yang bisa dilakukan dimanapun, kapanpun, serta tidak adanya batasan waktu. Pendidikan memegang peranan penting terhadap kemajuan pembangunan bangsa. Kualitas sumber daya manusia yang mempunyai daya saing juga tidak terlepas dari pendidikan. Dunia Pendidikan banyak mendapat perhatian dari pemerintah, dalam rangka meningkatkan kualitas pendidikan yang nantinya bermuara pada perkembangan sumber daya manusia. Sekolah merupakan salah satu lembaga yang mempunyai peranan penting dalam mengembangkan potensi siswa, tetapi juga menanamkan nilai-nilai yang mendukung pembentukan dan pengembangan kepribadian anak tersebut. Selain itu sekolah juga mempunyai 
tanggung jawab untuk membantu dan menumbuh kembangkan minat serta potensi yang dimiliki anak tersebut.

Namun, salah satu permasalahan yang dihadapi bangsa indonesia saat ini adalah keberadaan anak putus sekolah. Anak putus sekolah adalah murid yang tidak dapat menyelesaikan program belajarnya sebelum waktunya selesai atau murid yang tidak tamat menyelesaikan program belajarnya. Adanya program wajib belajar 9 tahun dari pemerintah juga ternyata belum dapat menuntaskan permasalahan tingginya angka anak putus sekolah.

Banyak sekali faktor yang menyebabkan anak mengalami putus sekolah, diantaranya berasal dari dalam diri anak putus sekolah disebabkan malas untuk pergi ke sekolah karena merasa minder, tidak dapat bersosialisasi dengan lingkungan sekolahnya, sering dicemohkan karena tidak mampu membayar kewajiban biaya sekolah. Ketidakmampuan ekonomi keluarga dalam menopang biaya pendidikan yang berdampak terhadap masalah psikologi anak sehingga anak tidak bisa bersosialisasi dengan baik dalam pergaulan dengan teman sekolahnya. Selain itu adalah karena pengaruh teman sehingga ikut-ikutan diajak bermain sampai akhirnya sering membolos dan tidak naik kelas, prestasi di sekolah menurun dan malu pergi kembali ke sekolah.

Dengan peran serta pemerintah, masyarakat, maupun orang tua dapat berpartisipasi dalam mengatasi anak putus sekolah dengan peran orang tua, motivasi dan perhatian yang dilakukan membuat anak bersemangat untuk bersekolah. Berdasarkan observasi awal penulis, di desa Mapila banyaknya anak putus sekolah, mulai dari usia 10-17 tahun, pada tingkat SD terdapat 10 orang anak, pada tingkat SMP terdapat 9 orang anak, pada tingkat SMA terdapat 5 orang anak putus sekolah. Jika ditotalkan maka keseluruhannya 24 orang anak yang putus sekolah di Desa Mapila.

\section{Konsep Anak}

Arismantoro (2008: 123) memberikan defenisi anak adalah muiara kehidupan yang diamantkan Allah kepada orang tua, kehadirannya senantiasa memberi arti untuk menggagas kanvas kehidupan mendatang. Sejatinya anak adalah pemilik masa depan.

Dalam Undang-Undang No. 35 Tahun 2014 tentang perubahan atas Undang-Undang No. 23 tahun 2002 tentang Perlindungan Anak pasal 1 tersebut menjelaskan bahwa: Anak adalah seorang yang belum berusia 18 tahun termasuk anak yang masih dalam kandungan. Perlindungan anak adalah segala kegiatan untuk menjamin dan melindungi anak hak-haknya agar dapat hidup, tumbuh berkembang, dan berpartisipasi, secara optimal sesuaidenganharkat dan martabat kemanusiaan, serta mendapat perlindungan dari kekerasan dan diskriminasi. Dalam Undang-Undang Nomor 39 Tahun 1999 tentang hak asasi manusia pasal 1 butir 5 bahwa: Anak adalah setiap manusia yang berusia dibawah 18 (delapan belas) tahun dan belum menikah, termaksud anak yang masih dalam kandungan apabila hal tersebut adalah demi kepentingannya.

\section{Konsep Putus Sekolah}

Menurut Kaufman (Desca, 2015:4) mendefinisikan putus sekolah adalah murid yang tidak dapat menyelesaikan program belajarnya sebelum waktunya selesai atau murid yang tidak tamat menyelesaikan program belajarnya. Menurut 
Darmaningtyas (Ni Ayu Krisna Dewi, 2014: 5) putus sekolah adalah suatu keadaan terhentinya aktivitas pendidikan pada anak-anak usia sekolah, baik itu pendidikan formal maupun pendidikan informal sebelum mendapatkan pengetahuan yang cukup untuk bertahan hidup dalam masyarakat. Putus sekolah adalah siswa secara terpaksa dari suatu Lembaga pendidikan tempat dia belajar. Anak putus sekolah yang dimaksud adalah terlantarnya anak dari sebuah pendidikan formal, yang disebabkan oleh berbagai faktor.

\section{Faktor Penyebab Anak Putus Sekolah}

1. Faktor Internal Penyebab Anak Putus Sekolah

Menurut Suyanto(Sriwahyuni, 2013: 3) faktor internal penyebab anak putus sekolah adalah sebagai berikut:

a. Rendahnya Minat atau Kemauan Anak Untuk Bersekolah

Pendidikan tanggung jawab keluarga terutama orang tua, akan tetapi tanggung jawab juga harus disertai dengan kemauan dari anak itu sendiri untuk sekolah. Antara pendidikan dan minat anak merupakan satu sisi yang saling membutuhkan dan saling mempengaruhi. Tingkat motivasi seorang anak sangat berpengaruh terhadap keinginan anak untuk terus bersekolah, motivasi ini bisa berasal dari keluarga, lingkungan dan anak itu sendiri.

Menurut Desca (2015: 7) memaparkan bahwa penyebab anak putus sekolah diutamakan karena rasa minat untuk bersekolah tidak ada (malas). Ada kemauan dari dalam diri anak untuk bersekolah yang sangat kurang, karena kemauan belajarnya yang rendah, karena faktor kejenuhan, kebosanannya untuk bersekolah. b. Sekolah Dianggap Tidak Menarik

Sekolah dianggap tidak menarik bagi anak karena tugas dan beban di sekolah yang tidak mampu diikutinya, dan juga aturan sekolah yang merasa menjadi beban baginya sehingga merasa menjadi penghalang bagi kebiasaannya, juga karena kemampuan belajar yang rendah, dan merasa tidak nyaman dan minder saat bersekolah, hal tersebut menjadikan sekolah tidak menarik lagi baginya.

c. Ketidak Mampuan Mengikuti Pelajaran

Kemampuan anak dalam belajar sangat rendah karena anak merasa pelajaran yang diberikan guru di sekolah sangat sulit baginya, dan malah terkadang apabila tidak paham maka dia lebih memilih diam dan tidak mau bertanya. Merasa tidak percaya diri juga dengan jawaban sendiri. Ada juga anak yang kemampuannya dalam belajar sangat bagus namun karena alasan tertentu maka dia memutuskan untuk tidak bersekolah juga.

2. Faktor-Faktor Eksternal Penyebab Anak Putus Sekolah

Menurut Suyanto (Sriwahyuni, 2013: 4) faktor-faktor eksternal penyebab anak putus sekolah adalah sebagai berikut:

a. Ekonomi Keluarga

Sebagian anak putus sekolah karena ekonomi keluarganya yang sangat susah, sehingga membuatnya merasa terpaksa untuk meninggalkan sekolah, sebagian lagi karena memang kemampuan dan kemauannya untuk bersekolah yang tidak ada sehingga meninggalkan sekolah sebelum saatnya. Sebagian orang merasakan bahwa pendidikan merupakan beban yang paling berat dan mahal tidak mampu mereka menjangkaunya, apabila pendidikan sekarang yang sudah mahal membuat orang tua mengeluh dengan biaya yang mereka punya jadi inilah yang 
membuat putus sekolah. Kemiskinan menyebakan anak berhenti sekolah dan terpaksa membantu pekerjaan orang tua untuk meringankan beban oran tua dan mendapatkan penghasilan tambahan. Meski sudah ada kemudahan dari sekolah untuk orang tua membayar SPP anak-anaknya dengan menyicil, tetapi masih ada juga yang putus sekolah karena faktor ekonomi orang tua.

b. Kurangnya Perhatian Orang Tua

Sebagian anak putus sekolah karena kurangnya perhatian orang tuanya hanya sibuk bekerja dan tidak memperhatikan sekolah anaknya, tapi memang semua karena ekonomi keluarganya yang susah, sehingga membuatnya merasa terpaksa untuk meninggalkan sekolah, sebagian lagi karena memang kemampuan dan kemaunnya untuk bersekolah yang tidak ada sehingga meninggalkan sekolah yang belum saatnya.

c. Lingkungan Bermain

Banyak ahli psikologi perkembangan atau pengamat perkembangan anak mempertimbangan tekanan teman sepermainan membawa konsekuensi negatif dan hubungan persahabatan sekaligus dari rekan mereka. Ketika anak mampu menolak pengaruh rekan-rekan mereka, terutama dalam situasi atau membingungkan mereka mungkin mulai merokok, minum alkohol, mencuri, atau mengasingkan diri dari teman-temannya.

Ada beberapa faktor yang menyebabkan anak tidak sekolah (Sarfa Wassahua 2016: 104-106) antara lain :

1. Faktor Pendapatan Orang Tua

Penyebab anak tidak sekolah adalah faktor ekonomi, yaitu mencapai $36 \%$. Faktor ekonomi yang dimaksudkan adalah ketidakmampuan keluarga si anak untuk membiayai segala proses yang dibutuhkan selama menempuh Pendidikan atau sekolah dalam satu jenjang tertentu. Walaupun pemerintah telah mencanangkan wajib belajar 9 tahun, namun belum berimplikasi secara maksimal terhadap penurunan jumlah anak tidak dan putus sekolah.

2. Faktor Motivasi dan Minat

Rendahnya minat anak dapat disebabkan oleh perhatian orang tua yang kurang, jarak antara tempat tinggal anak dengan sekolah yang jauh, fasilitas belajar yang kurang dan pengaruh lingkungan sekitarnya. Minat yang kurang dapat disebabkan oleh pengaruh lingkungan, misalnya tingkat Pendidikan masyarakat rendah yang diikuti oleh kesadaran tentang pentingnya pendidikan.

3. Faktor Perhatian/Persepsi Orang Tua Terhadap Pendidikan

Rendahnya perhatian orang tua terhadap anak dapat disebabkan karena kondisi ekonomi keluarga atau rendahnya pendapatan orang tua si anak sehingga perhatian orang tua lebih banyak tercurah pada upaya untuk memenuhi kebutuhan keluarga. Persentase anak yang tidak dan putus sekolah kurangnya perhatian orang tua. Dalam keluarga miskin cenderung timbul berbagai masalah yang berkaitan dengan pembiayaan hidup anak, sehingga mengganggu kegiatan belajar dan kesulitan mengikuti pelajaran.

4. Faktor Prasarana Sekolah

Faktor prasarana yang dimaksud adalah terkait dengan ketidaktersediaan prasarana pendidikan berupa gedung sekolah atau alat transportasi dengan tempat tinggal siswa dengan sekolah. Masalah ini sering terjadi di sekolah-sekolah yang berada di pedesaan, maupun di wilayah pedalaman seperti hutan. Alat transportasi yang kurang serta jarak antara rumah dengan sekolah yang cukup jauh. 


\section{Faktor Fasilitas Belajar}

Fasilitas belajar yang dimaksud adalah fasilitas belajar yang tersedia di sekolah, misalanya perangkat (alat, bahan, dan media), pembelajaran yang kurang memadai, dan sebagainya. Kebutuhan dan fasilitas belajar yang dibutuhkan siswa tidak dapat dipenuhi siswa, dapat menyebabkan turunnya minat anak yang pada akhirnya menyebabkan putus sekolah.

6. Faktor Budaya

Faktor budaya yang dimaksud disini adalah terkait dengan kebiasaan masyarakat di sekitarnya, yaitu rendahnya kesadaran orang tua atau masyarakat akan pentingnya pendidikan. Perilaku masyarakat dalam menyekolahkan anaknya lebih banyak dipengaruhi faktor lingkungan. Mereka beranggapan tanpa bersekolahpun anak-anak mereka dapat hidup layak seperti anak lainnya yang bersekolah. Oleh karena di desa jumlah anak yang tidak bersekolah lebih banyak dan mereka dapat hidup layak maka kondisi seperti itu dijadikan landasan dalam menentukan masa depan anaknya.

7. Faktor lainnya, adalah cacat, IQ rendah, rendah diri, dan umur yang melampaui usia sekolah. Persentase anak yang putus sekolah yang disebabkan karena faktor ini sangan sedikit, yaitu kurang dari $1 \%$. Begitu juga untuk kategori anak tidak sekolah sama sekali, faktor penyebabnya adalah karena ekonomi disamping faktor sarana, minat yang kurang, perhatian orang tua yang rendah, dan fasilitas yang kurang.

\section{Upaya Orang Tua dan Sekolah dalam Mengatasi Anak Putus Sekolah}

1. Upaya Orang Tua

Menurut Janu (2004: 42) keluarga sebagai kesatuan sosial terkecil dan paling utama bagi tercapainya kehidupan sosial masyarakat yang memiliki fungsifungsi pokok, yaitu pemenuhan kebutuhan biologis, emosional, pendidikan, dan sosial ekonomi. Pengawasan dan bimbingan orang tua di rumah mutlak diperlukan karena adanya bimbingan orang tua dalam mengawasi dan mengetahui kekurangan dan kesulitan belajar anak (Tatang, 2012: 85).

2. Upaya Sekolah

Menurut Fitriana (Salni Yanti 2017: 22) bahwa upaya yang dilakukan sekolah dalam mengatasi anak putus sekolah adalah :

a. Pihak sekolah beserta Kepala Sekolah dan Wali Kelas memberikan nasehat atau mengupayakan yang terbaik untuk anak agar mencari solusi dari permasalahan yang dihadapi anak.

b. Dengan pemanggilan orang tua atau wali di sekolah terkait memberikan pemahaman bagaimana pentingnya pendidikan bagi anak kedepannya.

\section{METODE PENELITIAN}

\section{Lokasi dan Waktu Penelitian}

Penelitian ini dilaksanakan di desa Mapila Kecamatan Kabaena Utara Kabupaten Bombana dengan pertimbangan bahwa di desa Mapila Kecamatan Kabaena Utaraterdapat anak putus sekolah yang tidak dapat menyelesaikan masa pendidikannya disuatu jenjang pendidikan, baik dari tingkat SD, SMP., dan SMA. 


\section{Jenis Penelitian}

Jenis Penelitian ini adalah Deskriptif dengan menggunakan metode campuran (Mix Method), dimana peneliti memberikan uraian secara deskriptif tentang faktor-faktor penyebab anak putus sekolah di desa Mapila Kecamatan Kabaena Utara Kabupaten Bombana.

\section{Populasi dan Sampel}

Populasi dalam penelitian ini adalah seluruh anak-anak yang ada di desa Mapila Kecamatan Kabaena Utara Kabupaten Bombana yang putus sekolah sebanyak 24 orang.

Sebagaimana jumlah populasi tersebut di atas, peneliti mengambil sampel dengan menggunakan teknik sampel Insidental dimana dari 24 orang responden peneliti menemukan sampel 14 orang responden di desa Mapila Kecamatan Kabaena Utara Kabupaten Bombana.

\section{Informan Penelitian}

Sebagai informan dalam penelitian ini terdiri dari orang tua siswa yang putus sekolah berjumlah 3 orang, tokoh masyarakat 1 orang, kepala desa 1 orang, kepala sekolah 2 orang, guru SD 2 orang, dan guru SMP 1 orang.

\section{Teknik Pengumpulan Data}

Untuk memperoleh data yang dibutuhkan dalam penelitian ini digunakan tehnik sebagai berikut::

1. Angket (quetionaire), yaitu teknik pengumpulan data yang dilakukan dengan cara memberikan sejumlah pertanyaan yang telah dipersiapkan pilihan jawaban mengenai faktor yang menjadi penyebab anak putus sekolah di desa Mapila Kecamatan Kabaena Utara Kabupaten Bombana.

2. Observasi yaitu mengumpulkan data dengan mencatat dan melakukan pengamatan secara tidak langsung terhadap objek penelitian guna memperoleh data tentang faktor penyebab anak putus sekolah di desa Mapila Kecamatan Kabaena Utara Kabupaten Bombana.

3. Wawancara yaitu mengadakan tanya jawab secara langsung dengan pihakpihak yang terkait dengan penelitian ini. Wawancara dalam penelitian ini dilakukan dengan mendatangi langsung informan penelitian dan menanyakan kepada mereka beberapa hal yang berhubungan dengan pokok permasalahan. Wawancara dilakukan secara mendalam untuk memperoleh data langsung melalui serangkaian tanya jawab dengan pihak-pihak yang terkait dengan faktor penyebab anak putus sekolah di desa Mapila Kecamatan Kabaena Utara Kabupaten Bombana.

4. Dokumentasi yaitu pengambilan data-data yang berhubungan dengan masalah dalam penelitian ini yakni dokumen-dokumen yang relevan, foto, serta catatan yang berkaitan dengan faktor penyebab anak putus sekolah di desa Mapila Kecamatan Kabaena Utara Kabupaten Bombana.

\section{Teknik Analisis Data}

Dalam peneliitian ini peneliti menggunakan teknik analisis data yang bersifat deskriptif kualitatif dan kuantitatif (mix method) dengan serangkaian langkah yang di ambil untuk memeriksa validitas data kuantitatif dan akurasi hasil 
kualitatif, menurut jhon $\mathrm{w}$ Creswell (Salni Yanti, 2017: 27) menyebutukan beberapa analisis data mixed method yaitu:

1. Transformasi data, dalam strategi peneliti bisa saja menghitungkan data kuantitaif atau sebaliknya peneliti juga dapat mengklasifikasi data kuantitaif

2. Mengeksplorasi, dalam strategi analisis data kuantitatif pada tahap pertama dapat menghasilkan analisis penelitian setelah itu dapat menindak lanjuti dengan wawancara kualitatif tentang masalah penelitian untuk memperoleh informasi tentang masalah yang diteliti.

3. Instrument, dengan instrument survey kuantitatif pada tahap ini menvalidasi sampel yang dari populasi

4. Mengumpulkan hasil-hasil kuantitaif dengan sampel pada waktu bersamaan lakukan wawancara kualitatif mengenai masalah dalam penelitian

5. Membuat table, dengan mengkobinasikan informasi-informasi yang diperoleh dari pengumpulan data kuatitaif dan kualitatif ke dalam bentuk tabel.

\section{HASIL PENELITIAN DAN PEMBAHASAN}

Dalam penelitian ini sebagaimana hasil penelitian di lapangan yang telah dilakukan faktor penyebab anak putus sekolah di desa Mapila dipengaruhi oleh beberapa faktor penyebab, yakni faktor internal dan eksternal antara lain sebagai berikut:

1. Faktor Internal Penyebab Anak Putus Sekolah

a. Rendahnya Minat atau Kemauan Anak Untuk Bersekolah

Berdasarkan data dilapangan,dapat di deskripsikan bahwa respon anak mengenai rendahnya minat dan kemauan anak untuk bersekolah sebagai faktor putus sekolah yang menyatakan Ya berjumlah 8 orang atau 57,14\%, dan yang menjawab Tidak berjumlah 6 orang atau 42,85\%,

b. Sekolah dianggap tidak menarik

Berdasarkan data dilapangan, dapat di deskripsikan bahwa respon anak mengenai sekolah dianggap kurang menarik sebagai faktor putus sekolah yang menyatakan Ya berjumlah 9 orang atau 64,28\%, dan yang menjawab Tidak berjumlah 5 orang atau $35,71 \%$.

c. Ketidakmampuan mengikuti pelajaran

Berdasarkan data dilapangan, dapat di deskripsikan bahwa respon anak mengenai ketidakmampuan mengikuti pelajaran sebagai faktor putus sekolah yang menyatakan Ya berjumlah 6 orang atau 42,85\%, dan yang menjawab Tidak berjumlah 8 orang $57,14 \%$.

2.Faktor Eksternal Anak Putus Sekolah

a. Ekonomi Keluarga

Berdasarkan data dilapangan, dapat di deskripsikan bahwa respon anak mengenai kemampuan orang tua membiayai pendidikan dan menyediakan fasilitas selama bersekolah sebagai faktor putus sekolah yang menyatakan Ya berjumlah 5 orang atau $35,71 \%$, dan yang menyatakan Tidak berjumlah 9 orang atau $64,28 \%$.

b. Kurangnya Perhatian Orang Tua

Berdasarkan data dilapangan, dapat di deskripsikan bahwa respon anak mengenai kurangnya perhatian orang tua akan pendidikan sebagai faktor putus sekolah yang menyatakan Ya berjumlah 10 orang atau $71,42 \%$, dan yang menyataakan Tidak berjumlah 4 orang atau 29, $57 \%$.

c. Lingkungan Bermain 
Berdasarkan data dilapangan, dapat dideskripsikan bahwa respon anak mengenai lingkungan bermain dan sosial sebagai faktor putus sekolah yang menyatakan Ya berjumlah 8 orang atau $57,14 \%$, dan yang menjawab Tidak berjumlah 6 orang atau $42,85 \%$.

d. Jauhnya jarak antara rumah ke sekolah

Berdasarkan data dilapangan, dapat di deskripsikan bahwa respon anak mengenai jauhnya jarak antara rumah dan sekolah sebagai faktor penyebab anak putus sekolah yang menyatakan Ya berjumlah 5 orang atau 35,71\%, dan yang meyatakan Tidak berjumlah 9 orang atau 64, 28\%.

\section{Upaya Orang Tua dan Sekolah dalam Mengatasi Anak Putus Sekolah 1. Upaya Orang Tua}

Berdasarkan hasil wawancara dilapangan, maka dapat diketahui upaya orang tua itu sangat penting dengan memberikan motivasi-motivasi, rasa peduli, menyemangati, mensuport, memberi perhatian serta memenuhi apa yang menjadi kebutuhannya di sekolah dan mengontrol pergaulan anak, sehinnga anak dapat termotivasi kembali untuk bersekolah untuk menggapai cita-citanya demi masa depan yang lebih baik dengan pendidikan.

\section{Upaya Sekolah}

Berdasarkan hasil wawancara di lapangan dalam penelitian ini, dapat diketahui upaya sekolah untuk mengatasi faktor penyebab anak putus sekolah di desa Mapila baik itu faktor internal maupun eksternal dengan memperbaiki sarana sekolah, mengadakan kegiatan ekstrakulikuler dan memberikan perlengkapan kegiatan-kegiatan sekolah agar sekolah menjadi nyaman bagi siswa dan tidak lagi bolos-bolosan, serta menjalin kedekatan dengan siswa dan orang tua siswa apabila ada masalah yang dihadapi yang berkaitan dengan kebutuhan sekolah siswa sehingga cepat dicarikan solusi agar anak tetap melanjutkan pendidikan.

\section{PENUTUP}

\section{Kesimpulan}

Berdasarkan hasil penelitian dan uraian dalam pembahasan, maka dapat disimpulkan sebagai berikut:

1. Faktor-faktor penyebab anak putus sekolah di desa Mapila dipengaruhi oleh dua faktor yaitu faktor internal yang meliputi kurangnya minat atau kemauan anak, sekolah diaggap kurang menarik dan ketidakmampuan mengikuti pelajaran. Sedangkan faktor eksternal meliputi keterbatasan ekonomi orang tua, kurangnya perhatian orang tua, lingkungan bermain, dan jauhnya jarak antara rumah dan sekolah. Dari semua faktor tersebut untuk faktor internal yang mendominasi adalah faktor rendahnya minat atau kemauan anak untuk sekolah sedangkan faktor eksternal yang mendominasi adalah faktor kurangnya perhatian orng tua.

2. Upaya mengatasi penyebab anak putus sekolah yang dilakukan di desa Mapila yaitu :

a. Orang tua harus memperhatikan dan sadar akan pentingnya pendidikan anak, berusaha memberikan dukungan dan motivasi baik dari segi moral maupun material.

b. Sekolah dalam mengatasi anak putus sekolah baik itu faktor internal maupun faktor eksternal yang dilakukan pihak sekolah yaitu melengkapi sarana dan prasarana sekolah, serta menjalin kedekatan dengan siswa dan 
orang tua siswa, pemanggilan orang tua siswa, serta mengunjungi rumah orang tua siswa untuk mengetahui apa kendala sehingga anak putus sekolah untuk kemudian mencari solusi agar anak tetap melanjutkan pendidikan formal.

\section{Saran}

Adapun saran yang dapat penulis sajikan sehubungan dengan faktor penyebab anak putus sekolah pendidikan dasar di desa Mapila adalah :

1. Orang tua harus mempunyai semangat yang besar dalam menyekolahkan anak mereka. Orang tua harus memberikan perhatian lebih terhadap pendidikan anak dengan berusaha menciptakan lingkungan belajar yang aman dan mengupayakan agar selalu berkomunikasi dengan pihak sekolah untuk mengetahui perkembangan anak di sekolah, mengontrol pergaulan anak, memperhatikan apa yang menjadi masalah anak, memenuhi kebutuhan anak dan jangan menjadikan ekonomi lemah sebagai alasan anak putus sekolah.

2. Dari pihak sekolah diharapkan guru dan semua personil sekolah dapat memberikan perhatian khusus bagi siswa yang mulai menunjukkan sikap malas untuk berangkat ke sekolah dan memberikan solusi penyebab dari masalah anak putus sekolah. Dari pihak kepala sekolah agar lebih memperhatikan sarana dan prasarana sekolah, pelayanan agar siswa dapat betah di sekolah serta pendidikan siswanya dan memberikan arahan serta dukungan akan pentingnya pendidikan formal bagi masa depan mereka.

\section{DAFTAR PUSTAKA}

Arismantoro. 2008. Tinjauan Berbagai Aspek Character Building: Bagaimana Mendidik Anak Berkarakter. Yogyakarta : Tiara Wacana

Desca, Thea Purnama. 2015. Fenomena Anak Putus Sekolah Dan Faktor Penyebabnya di Kota Pontianak. Jurnal Eksekutif

Murdiyatmoko, Janu. 2004. Memahami dan Mengkaji Masyarakat. Jakarta: Grafindo Media Pratama.

Ni Ayu Krisna Dewi. 2014. Analisis Faktor-Faktor Penyebab Anak Putus Sekolah Usia Pendidikan Dasar di Kecamatan Gerokgak Tahun 2012/2013. Jurnal Eksekutif.

Republik Indonesia. Undang-Undang Nomor 35 Tahun 2014 Tentang Perubahan Atas Undang-Undang Nomor 23 Tahun 2002 Tentang Perlindungan Anak. Jakarta: Fokus Media

Republik Indonesia. Undang-Undang Nomor 39 Tahun 1999 Tentang Hak Asasi Manusia. Jurnal Diakses Melalui https://www. Google.Com/2019/8

Sriwahyuni, Deswita. 2013. Faktor Penyebab Remaja Putus Sekolah (Studi di Desa Koto Gunung Kecamatan Batang Kapas Kabupaten Pesisir Selatan). Jurnal Eksekutif.

Tatang. 2012. Ilmu Pendidikan. Bandung: Pustaka Setia.

Wassahua, Sarfa. 2016, "Analisis Faktor-faktor Penyebab Anak Putus Sekolah di Kampung Wara Negeri Hative Kecil Kota Ambon”. jurnal.iainambon.ac.id tanggal 20 September, pukul 11.00 WIB.

Yanti, Salni. 2017. "Faktor-Faktor Penyebab Anak Putus Sekolah Jenjang Pendidikan Dasar 9 Tahun (Studi di Desa Bonea Kecamatan Lasalepa 
Kabupaten Muna)". (Skripsi). Kendari: Jurusan Pendidikan Pancasila Dan Kewarganegaraan, FKIP, Universitas Halu Oleo. 